\title{
HYBRID STRATEGIC IDENTITIES AS GENDERED RESOURCES IN FRENCH POLITICS (MARTINE AUBRY AND MARINE LE PEN)
}

\author{
Author: BAIDER, Fabienne \\ Associate Professor - University of Cyprus - Nicosia (Cyprus) - fabienne@ucy.ac.cy
}

\begin{abstract}
Many researchers such as Sineau (2001), Bertini (2002), Achin et al (2007) have been for years denouncing the "male norm or the male political order" in French politics. They also argue that explanations for such a gendered field should not be based on status differences between men and women but should focus on how dominant relationships differentiate male behavior and female behavior in politics. In this paper, we examine how, in their 2012 presidential campaigns, Martine Aubry (a socialist leader) and Marine Le Pen (an extreme-right party leader) adopted traditionally masculine strategic identities, and how these were portrayed in the French press. Both female politicians were known for their 'toughness'; however Aubry was noted as being emotional, while Le Pen was seen to emphasize family life. They embodied a 'femininity with a twist'. In order
\end{abstract}

to examine the reception of such hybrid personas in journalistic discourse, we examine articles published in the French mainstream press, using quantitative and qualitative approaches. We point out the shared and different strategies and conclude on the periperformativity on the part of the newspapers as far as these 'gender acts' are concerned.

\section{Key words}

French politics, masculinity, Aubry, Le Pen, androgyny, periperformativity.

\section{Introduction}

The 2000 parity law in France aimed at rejuvenating and feminizing the political arena; it also ensured a balance of the sexes in the political bodies by requiring electoral lists to be $50 \%$ female. Yet women are poorly represented in the French political space; for instance, female politicians have always been (and are still) extremely under-represented in the Parliament and the Senate, their numbers even lower than other Latin countries, a point which rules out the "culturalist" explanation of Achin and
Levêque (2012). In fact, the French political sphere is highly gendered. It is horizontally segregated, with portfolios such as economy and agriculture typically held by men, while women are usually appointed/elected to deal with areas such as education and culture. It is also vertically stratified, with men holding the most prestigious and better paid positions (Bertini 2002; Freedman 1997; Sineau 2007; Achin and Levêque 2012).

\section{Objectives}

Even though the male political order is preserved, the parity law in politics made it possible for a short period (2000-2001) for women candidates to capitalize on deemed feminine qualities such as proximity to the electorate or a more concrete approach to politics (Achin et al. 2007; Allan \& Mas 
2007). A few years later (2007), S. Royal quite openly played on femininity in her campaign. Indeed, the Sarkozy and Royal candidatures were considered to be somewhat 'exceptional' cases: as French voters and French commentators noted, Royal and Sarkozy were candidates who, for the first time in French political history, played on sexual stereotypes (Gingras 1996; Achin \& Dorlin 2008; Coulomb-Gully 2009, 2012). Yet, Royal was castigated for taking this approach, while Sarkozy was celebrated for his virile style. In the last presidential campaign (2012) things seemed different: female candidates such as Martine Aubry (then head of the Socialist party) and Marine Le Pen (president of the Front National party) tended to use the opposite strategy, displaying an obvious physical and behavorial 'masculinity'. In this article we will examine how this reversal is translated in the journalistic discourse.

\section{Methodology}

For each politician, we look at a corpus of articles focused on both candidates, published during the period March - July 2011-- a time when the general presidential campaign was underway and before the socialist primaries were held (in which M. Aubry lost in October 2011). We built the corpus from six different daily newspapers (regional and national newspapers, representing a wide political spectrum from left to right). The six newspapers we examined were the following: four national dailies-- Libération, Le Monde, Le Figaro, La Croix, and two regional dailies-- Ouest-France and Est-Républicain; from these, twenty articles were selected for each candidate (a total of 120 articles for each) ${ }^{1}$, making a total of 59, 909 words for Martine Aubry and 61, 784 words for Marine Le Pen. The software Termostat (Lesage et al. 1993; Drouin 2003) was used to examine both the most frequent and the most specific lexical categories for each name under study. More precisely, we worked with the most frequent collocations found in the context of the Noun Phrase under investigation (such as primaire socialiste = socialist primary) and the most specific collocations for that NP (such as secretaire du parti socialiste for Martine Aubry). The specificity parameter is an important dimension in corpus linguistics, and is defined as "the calculation of the difference between the relative frequencies of the linguistic items in the analysis and reference corpora": it is thus the difference in frequency of lexical items in our data in relation to the 'reference corpus' (28 million words)

\footnotetext{
${ }^{1}$ See Baider \& Jacquey (2014) for methodology and corpus description.

${ }^{2}$ TermoStat

(http://linguistech.ca/TermoStat_E_TUTCERTT_I_PartI)
}

from Le Monde (2002). To appraise the ideological dimension of the texts under study, we restrict our analysis to the lexical marking (collocations, specificities and frequencies of lexical units) based on earlier studies (Banks 2007; Bednarek 2008; Blumenthal 2002; Sinclair 2004; Tutin et al. 2006; Van Dijk 2006).

Qualitatively, analysis of the collocational properties of the nouns associated with the politicians will reveal the newspaper's value and belief system. Analyzing the paragraphs where the NP of each candidate appears in the article will show us the contextual environment of the lexical units and collocates under investigation. We worked on what is known as Key Word in Context (KWIC) where the noun of each candidate appears in the article. This contextual environment will give the semantic prosody (Bednarek 2008) of the discourse in which the most frequent or more specific lexical units are embedded; the semantic prosody in turn will enable to us assess whether the evaluation was positive or negative. 


\section{Political resources and gendered identity}

Stereotypes of femininity and masculinity are not simply images; they are formulations that are internalized, incorporated, embodied, and with practical consequences (Achin et al. 2007, p. 17; Allan \& Mas 2007). Politicians, for instance, often adopt strategic identities linked to their gender.

\subsection{Strategic identities of candidates and sexual personas}

Of the resources available to politicians, the most important for political success are economic, cultural and social. These resources can be divided into two categories: the private persona (personality, education, occupation, social origin, political experience); the collective persona (political brand, engagement, associative militancy, etc.). However, for men, gender is a kind of symbolic capital, just as the body is a symbolic resource for women in politics (Achin et al. 2007, p. 71).

Such resources depend on the political contexts in which they are mobilized. Therefore, studies focused on French politics should recognize the domination relationship, which differentiates and prioritizes male behavior over female behavior (this will be discussed later in section1.3). As a matter of fact, in French politics women have been pushed into 'peripheral political markets' (Achin \& Levêque 2012; CoulombGully 2012), and therefore have great difficulty making it to presidential elections, although Martine Aubry, Ségolène Royal and Marine Le Pen were all successful in this.

Choosing a strategic identity in order to win is understandably a difficult dilemma for French female politicians since political roles have been historically defined by their exclusion and have always been embodied by men. As a matter of fact, playing on femininity as a resource is always dangerous in politics: this resource is fragile and can lead to a negative outcome (Achin et al. 2007, 57). Indeed playing on femininity is to risk being stigmatized for it: women who choose to portray themselves as compassionate and/or close to the electorate will be deemed mother-like, not a positive quality for the tough life of politicians. They are continually threatened by a "salto stigma"-- a reversal of their intent that results in disqualifying labels, typically labels like Passionaria or Madonna (Coulomb-Gully 2012; Bertini 2002). As we will see in section 1.2, S. Royal is a good example of the phenomenon.

However, women who present male qualities run other risks. Efficient and distant, they will be said to be cold and bossy, maybe frigid, certainly inhuman (Freedman 1997, p. 204; Allan \& Mas 2007). This double bind is a constant in political life: women are described, at the same time and depending on circumstances, as unsympathetic power-mongers but prone to emotional outbursts; too tough and brusque but weak because of a tendency to negotiate. The double bind goes hand-in-hand with a gendered interpretation of actions and emotions. For instance, a display of anger can be seen as a sign of status in men (it shows sincerity), but for women it can signal incompetence (they cannot keep their cool) (Holmes 2004).

\subsection{Previous works on French politics, gendered identities and journalistic discourse: Royal vs.Sarkozy}

A case in point is the 2007 presidential elections. Many analysts view S. Royal's appearance in the elections as the first time that femininity and masculinity were used as symbolic capitals to win a powerful political position. In the campaigns leading up to the election, analysts suddenly recognized the importance of gender in the political game and the way in which gender affected the electorate's choice. Our own research on the 2007 presidential elections (Baider 2009; Baider \& Jacquey 2010, 2014) has suggested that by focusing on the noun phrases (NPs) referring to female and male politicians in journalistic discourses, we might understand each politician's 'linguistic portrait'. This linguistic portrait in turn would influence the electorate. We manually examined two corpuses of 19, 000 words for Royal and for Sarkozy taking into consideration the terms of address, the most commonly used verbs referring to the politicians, and their syntactic and semantic functions, as these were found in the three French daily newspapers Liberation, Le Monde and Le 
Figaro. We completed this qualitative study with a quantitative study on a bigger scale, with a corpus of approximately 60, 000 words for each politician. Using semantic analysis software (SEMY by Grzesitchak et al. 2007; Reutenauer et al. 2010 ) that used the definitions in the Trésor de la langue française informatisée (TLFi), we established the semantic fields defining each candidate (Royal and Sarkozy).

According to these data, the female politician (Royal) was portrayed as more on the defensive than on the attack. She was also seen to relate to the public to promote her ambitions, but not to present a detailed programme. On the other hand, Sarkozy was presented as a fighter who put his plans into motion, an important quality for a future head of state. In order to examine the actual causality of each protagonist, we examined the syntactic and semantic functions of each name in the journalistic discourse. The results supported a dichotomy between the noun Sarkozy functioning more often as a subject and an agent than Royal. These lexical and grammatical choices weakened Royal's position as presented in the discourse (Baider \& Jacquey 2010). These results corroborate Achin et al.'s 2012 analysis that Royal's gendered strategy, emphasizing that her role as a mother and her womanhood could not be seen as a positive difference in the actual political context. That strategy may have weakened her position as a potential leader.

Also noted by political observers was the different journalistic treatment of the two candidates' gendered strategy: if both politicians, Sarkozy and Royal, played on the continuum of masculinity / femininity, with Sarkozy wanting to appear as a sensitive man (Fassin 2008), there was little note of Sarkozy's gendered strategy, while Royal's made the (negative) headlines.

The most important is that for the first time, and under the Fifth Republic, sex and gender were used as obvious political resources. Also obvious was that the female politician suffered from this while the male candidate profited.

${ }^{3}$ Only available at the University Lorraine- ATILF

\subsection{Back to an all male-affair: 2012 presidential elections}

The 2012 presidential campaign was back to an allmale event, including the sexual scandal of the Dominique Strauss-Khan affair and the candidates playing on various masculinities, i.e., the alleged softness of F. Hollande and the paternalistic virility of Sarkozy. However Achin \& Levêque (2012) suggest that these male politicians may have used femininity by 'mediation'. They did not put forward their wives, as is nowadays often the case ${ }^{4}$, but they chose as main female spokespersons young, brilliant and goodlooking women: N. Vallaud-Balkacem for Francois Hollande and N. Kosciusko-Morizet for Nicolas Sarkozy. These women endorsed the traditional political division of labor: communication and appearance...

In the same presidential campaign, unsuccessful but noted female candidates such as Martine Aubry (socialist) and Marine Le Pen (Extreme-right) seemed to have played on the reversal of the stigma that Royal had suffered as mentioned previously. They displayed an obvious 'masculinity' in appearance and behavior (wearing trousers, tough talking, etc.). They even accused their adversaries of having qualities which were typically feminine: Marine le Pen labeling the opponent as "illogiques" (irrational) and Marine Aubry mocking François Hollande as being 'la gauche molle' (the softie).

\footnotetext{
${ }^{4}$ See, for instance, 'Wives becoming strategists for politicians', in 2014 Lok Sabha Elections, Instablogs Shimla: Athena Information Solutions Pvt. Ltd. (Apr 11, 2014)
} 


\section{Aubry and Le Pen: Femininity with a twist?}

\subsection{Aubry's political persona}

Known for her bad temper, Martine Aubry commonly refers to her colleagues by a variety of different 'bird names', and has labeled most of them as 'political zeros', F. Hollande included. She has also remarked that Hollande had no punch, and was 'la gauche molle' (spineless leftist), before he won the presidency. Her judgment is known to be pitiless and her criticism very sharp:

(elle est) réputée pour son mauvais caractère (...) les murs ont souvent résonné des noms d'oiseaux dont elle affuble ses « camarades » du parti. Martine Aubry a le jugement sévère et la critique acérée. Peu de socialistes trouvent grâce à ses yeux, beaucoup sont jugés « nuls ((She is) known for her bad temper $(. .$.$) the walls often resonated with bird nicknames$ that she bestowed on many of her "comrades" within the party. Martine Aubry makes harsh judgments and she is quite pointedly critical. Few socialists are spared her criticism, and she considers many to be "zeroes".) (Le Monde, 24.05.2011)

However she is also famous for her efficiency, determination, and courage. A hard worker, extremely well-organized and determined, she tends to be a perfectionist and is demanding of her co-workers: C'est une perfectionniste, elle est très exigeante, très angoissée. (Le Monde 24.05.2011). She is direct and frank, but she will apologize if she understands she has gone too far: Elle est directe, trop franche peut-être, mais lorsqu'elle s'en aperçoit, elle sait s'excuser. (Le Monde 24.05.2011) The conclusion is that she is a resilient woman: c'est une femme de caractère. (Le Monde 24.05.2011)

However, highlighting her masculine qualities meant that she was open to much criticism. Indeed, because she is demanding and does not mince her words, she has been nick-named Elena, after Elena Ceaucescu; suspicions circulated regarding her sexuality, and it was rumored that she was a lesbian although she was married twice and still is. Her lack of femininity was often commented upon. The political identity of female candidates does not escape sexualization: this may be a conscious decision made by political advisors; a slant chosen by journalists and cartoonists; a slander spread by political opponents.

As a result, her advisors suggested that she reinvent herself, and use her femininity as her symbolic capital.
For example, she was advised to say, even if it were not true, that she wanted to be the Mayor of Lille in order to spend more time "with the person she loves". This strategic characterization aimed to convince the electorate that she was indeed a heterosexual woman. It was also, especially for female voters, a way to show that she was leading a simple life (not true either) and could therefore share in the problems of the electorate (Achin 2007 et al., p.72). This strategy was actually not a choice but a response to articles that had disparaged her personally. Maybe this can also explain why her biographies record her, at least as far as her semi-public persona is concerned, as surprisingly prone to tears (Achin et al., 2007, p. 59). As the Minister of Employment and Solidarity in 1997, she was also said to have collapsed on her desk once back in her office after long and exhausting negotiations. Those instances of tears and apparent weakness are, according to one biographer, an illustration of "her internal debates, her hidden sensitivity and her fanciful temperament":

On connait également tant cela fait désormais partie de son personnage (semi)-public - les crises de larmes de Martine Aubry. Mise en récit par ses biographes autorisés, sa 'sensibilité' et sa 'fantaisie' (naturellement 'féminines' bien sûr) viennent en quelque sorte compenser et humaniser l' austérité' apparente de la ministre. (Also known now-- since they seem to be part of her (semi) -public persona -are Martine Aubry's tears. As narrated by her authorized biographers, her 'sensitivity' and her 'fanciful temperament' (naturally 'feminine' of course) somehow compensate and humanize the Minister's outward harshness) (Achin et al., 2007, 59).

She was to suffer from showing her emotional side. During the 2012 socialist primaries the press described her as tough and exacting, although 'too emotional', 'angry', and therefore too weak for office.

\subsection{Le Pen's political persona}

Often referred to as 'the daughter of Le Pen', Marine Le Pen aims at "de-demonizing" her far-right party to make it more presentable / palatable to voters on the traditional right; she denounces the label 'extreme right' for the FN. Taking great care of her image, she may have already transformed the FN into a populist people's party: since the FN became the first party in France during the 2014 European elections, it may be 
interpreted as a successful enlargement of the voters spectrum for the FN.

Despite being tall and athletic, she presents a femininity tailored to the working-class electorate (Achin \& Levêque 2012). For the first time in France, the extreme-right has managed to invent a politically feminine persona. Indeed, on forums and blogs she is often referred to by her first name, Marine, and her followers are called 'Marinists'. Moreover, as Shields (2013, pp. 190-191) and others have noted, the gender and the life choices of the new FN leader (twicedivorced and living out of wedlock) are radical changes in the leadership.

Her softer approach in politics has influenced the FN stance since 2002 (Shields 2007, 315), and on many sensitive social issues such as abortion, same sex marriage, gender parity and anti-Semitism. This enabled her to make gains with female voters, a vote that long eluded her father. Both her personality and her speeches are reassuring: she willingly recalls her own suffering (because of her childhood as Le Pen's daughter, a provocative politician), and she focuses on her compassion for the poor and the marginalized.
However, as Boudillon (2005, p. 80) noted, her physique and her speech, which are both very similar to her father's style, do not match traditional standards of femininity. Indeed, virility and populism are often associated in descriptions of Marine Le Pen (L'Express, 17.10.2002), an ethos which appears to constitute the populist persona of far-right leaders. Not afraid of being vulgar for the sake of being heard (La France est devenue la catin du Qatar = 'France has become Qatar's whore') may further evoke a "male femininity". Going even further, she accuses others of 'hysteria' ( the political system and the media), claiming to be 'the Voice of Reason', contradicting the stereotype of women being irrational.

Tears after a long day at work (Martine Aubry) or an eternal smile (Marine Le Pen), represent both typical 'feminine' behavior. Both were also 'chaperoned', which is often necessary for a woman to be credible as a politicians: Aubry and Le Pen benefitted from the association/protection of their political fathers. The two women seem to build their legitimacy by playing on their 'natural' manly aspect while trying at the same time to soften their personality. These language styles and physical appearances confuse genres and genders for both Marine Le Pen and Martine Aubry. How has this 'gender trouble' fared in the journalistic discourse?

\section{Linguistic findings: Comparing frequencies and specificities}

\subsection{Martine Aubry: a hybrid persona}

For Martine Aubry, our investigation found the following most frequent lexical items for the period MarchJuly 2011 in the six newspapers: candidat 'candidate', secrétaire 'secretary', 5 projet 'project', primaire 'primaries', parti 'Party', candidature 'candidacy', socialiste 'socialist', sondage 'opinion poll'.

All these lexical units are related to the general domain of politics (project, candidacy, party, primaries, socialist, etc.). They do not differentiate Aubry's persona, but they show that political resources are the most important (i.e., frequent) lexical items found for female politicians. And in fact, we find the same lexical items

\footnotetext{
${ }^{5}$ Martine Aubry was the First Secretary of the Socialist Party i.e. the leader of the party.
}

for male candidates whatever their party.

However, when considering the most specific terms for the candidate, we obtain the following list: maire 'mayor', ' appel 'call', avenir 'future', bureau 'office', convention 'convention', employ 'employment', entourage, envie 'to feel like', jeune 'young', jeunesse 'youth', leader, patronne 'female boss', porte-parole 'spokesperson', programme, rassemblement 'gathering', respect 'respect', ténor, unité 'unity'.

In the specific terms we can identify the main axes of Aubry's campaign: work (emploi), especially for the youth (jeune, jeunesse); respect, which symbolizes her campaign motto: a republic based on respect for the law

\footnotetext{
${ }^{6}$ Martine Aubry was at the time and still is the Mayor of Lille.
} 
and for people; unity, and gathering, which refer to her campaign message that she was able to unite the party behind her and has proven to be successful as Mayor of Lille.

On the negative side, however, we note the word patronne 'female boss, manageress'. The word itself is unusual in the context of politics, since it signals familiarity and a possible lack of respect. Indeed, the Trésor de la langue française, the French equivalent of the Oxford English dictionary, states that the word can be used as a synonym for 1. 'a boss, someone giving orders' and 2. 'a manager of a brothel' (patronne de maison close, de maison de rendez-vous). We can note that the male form of the word, patron, was only used twice in the data for male politicians, even when referring to Sarkozy who was known to be 'bossy'. In Aubry's case she was repeatedly referred to as the patronne --27 times in fact. Although journalists could also have used the male form, as a generic masculine and a common usage for positions of prestige, they never did. The masculine form, patron, is free of sexual innuendo and would be seen as less colloquial than the feminine form.

Moreover, the adjectives characterizing Aubry do not describe feminine traits, as this might be expected with the word patronne; they define the qualities typical of male candidates (distant, authoritarian, etc.) (Le Bart 2009):

Trop techno, trop loin des gens, trop autoritaire, trop brutale dans son management, trop parisienne: Martine Aubry est l'objet de toutes les critiques (Too technology inclined, too far away from ordinary people, too authoritarian, too brutal in her management, too Parisian : Martine Aubry is the topic of all criticism). (our italics) (Le Monde, 24.05.2011)

The discrepancy between the press's use of the feminine patronne and their more masculine description of Aubry reminds us of the androgyny noted in her portrait (section 3.1): she is a female boss but she behaves like a male manager, i.e., she is sexed (as a woman) but she does not have the social attributes of one, nor the expected behavior. Actually the problematic hybridity of her persona is explicitly mentioned several times:

(...) cette « mi-Mère Teresa, mi-despote, ni ange ni démon, entre la tentation de la compassion et celle de l'autoritarisme
». (this half-Mother Teresa, half bully, neither angel nor devil, between the temptation of compassion and of authoritarianism) (Le Monde, 13.06.2011)

This could be positive: away with the feminine weaknesses, and in with the masculine strength. However the opposite happens. Both the female noun (with the derogatory connotation of patronne) and the masculine adjectives (brutal, authoritarian, etc.) describe her in a negative light. And it is seen as disconcerting:

\footnotetext{
Tantôt empathique, tantôt misanthrope, hésitante et préparée, méfiante et entourée, affective et brutale, généreuse et acerbe (...) ses adversaires ne savent quel personnage affronter. (Sometimes sympathetic, sometimes misanthropic, hesitant and prepared, suspicious and surrounded by friends, emotional and brutal, generous and sharp (...) her opponents do not know which character to confront). (our italics) (Le Monde, 28.06.2011)
}

These descriptions could point towards instability of temperament and inconsistency in her actions, both very serious drawbacks for a potential leader, and both also labeled as typically female 'problems'.

\subsection{Marine Le Pen: the daughter of...}

For Marine Le Pen, the most frequent lexical items identified for the period March-July 2011 in the six newspapers are the following: tour 'voting turn', droite 'right wing', candidat, parti 'party', président, sondage 'opinion poll', élection, vote, canton 'canton, administrative district', voix 'vote'. Just as for M. Aubry, these most frequent lexical units describe the political domain (election, vote, candidate, party, etc.) and profile of the candidate (right wing, president of the party), hence the typical political resources of candidates.

However the most specific units reveal a similar 'disrupted/ disruptive' picture to that found for Aubry, i.e., a gendered dimension: père 'father', immigration, gens 'people', idée 'idea', institut, enquête 'survey', classe, république, peur 'fear', poussée 'push', protectionnisme, stratégie, fille 'daughter', laïcité 'secularity', alliance, internet, islam, mondialisation 'globalization', identité 'identity', ouvrier 'worker', préférence nationale.

The expressions, 'national preference', 'protectionism', and 'globalization', evoke her political strategy to protect the French against multiculturalism and global 
corporations. The words, Islam, fear, identity and secularity, very clearly make reference to the new focus of the National Front: the danger that she believes Islam presents to the French Republic. We note the gendered terms, 'father' and 'daughter', that lead the list of specificities and relegate the female politician Marine Le Pen to the private sphere. They mark her as first and foremost the daughter of the former National Front leader Jean-Marie Le Pen. As mentioned before, it is quite common for female politicians to be the daughter, the (ex-)wife, the mother or the friend of a famous male public personality. This means that their legitimacy can always be questioned: they are there because of a connection with a man, not because they deserve the position, not because they demonstrated they have the qualities for the position. In a word, they may be seen as illegitimate. In the case of Marine Le Pen, the word father as her most frequently mentioned specificity means that her identity is still extremely dependent on Jean-Marie Le Pen's aura, although she tries desperately to escape this association.

As for the adjectives describing M. Le Pen, they are very similar to those found for M. Aubry, as she is also found to be 'determined' and to deal with her party with 'authority':

Déterminée à concourir à l'élection présidentielle et à « accéder au pouvoir », elle imprime peu à peu, avec autorité, sa marque sur le mouvement qu'elle dirige depuis janvier. (Determined to compete for the presidential elections and "to achieve power", she makes her mark slowly, with authority, on the movement she has been heading since January.)(our italics). (La Croix, 29.04.2011)

There are other politicians who are equally determined-- for instance, F. Hollande has been described as even more determined than Le Pen or Aubry. Yet he is not described as affiliated with a 'father' figure as Le Pen is, or as emotional as Aubry is.

Moreover, the often vehement criticism of Marine Le Pen is indirect and concerns her programme. The shift to criticizing the female politicians is easy, since the adjectives used (dangerous, excessive, outrageous, ignorant, unrealistic, demagogic, authoritarian, irresponsible) can all be attributed to the leader:

Propositions plus irréalistes et dangereuses les unes que les autres, qui conjuguent l'autoritarisme avec l'étatisme, la démagogie avec l'outrance, l'ignorance avec l'irresponsabilité (Proposals which are more unrealistic and dangerous one than the other, which combine authoritarianism with statism, demagogy with excess, ignorance with irresponsibility) (our italics). (La Croix, 29.06.2011)

Another feature common to both politicians is that there is no atypical frequency in their data regarding typical feminine attributes, attributes which could be regarded as 'appealing' or enabling the politicians to create a seductive relationship with the electorate, as S. Royal did in 2007.

For instance, the noun sourire 'smile', the adjective souriant 'smiling' and the verb sourire 'to smile' are only found 4 times for Aubry (for some male politicians it was found more often), and they were generally paired with another adjective that balance (again) that feature with the candidate's seriousness or austerity: déterminée, sérieuse, mais souriante (determined, serious but smiling), un sourire tout en retenue (a selfcontrolled smile).

Like Thatcher, she is also described has having a regard de dame de fer (the gaze of an iron lady) but with un sourire de gamine (and the smile of a small girl), which are actually rather contradictory.

As for Marine le Pen, only once was the noun sourire used, and this was in a sentence discrediting her: despite her blond hair and her smile she could not hide the same agenda as her father «Le FN peut bien se cacher, se masquer, prendre les traits avenants d'un sourire, d'une blondeur, d'un prénom » (the FN can hide and disguise herself, take on the likeable features of a smile, of blond hair and of a first name) (Le Figaro, 28.06.2011). The paradigm féminine 'feminine', féminité 'femininity' was not recorded for either Aubry or Le Pen.

For both female politicians, therefore, we find typical feminine traits as well as many more manly ones. However, none of the descriptions offer the female politicians an advantage; both women seem to present the worst attributes of both genders. Indeed, this is confirmed by studies in the corpus focused on the typical masculine trait of competence (Freedman 1997; Olivesi 2012). 


\subsection{You said competence?}

In an earlier paper (Baider under revisions), we assessed the conceptual field of 'competence' in political discourse. The attributes found to be most necessary to successful politicians were the following: leadership, strategic, visionary, manager, experience, legitimate and credible.

In the table below we list the frequency (number of occurrences) of lexical units describing the qualities of competence, as found in the context of each noun:

\begin{tabular}{|c|c|c|}
\hline \multicolumn{3}{|c|}{ Table 1: Most frequent lexical units for both } \\
\hline \multicolumn{3}{|c|}{ names } \\
\hline & NP Aubry & NP Marine Le Pen \\
\hline leader, femme d'état & 2 & 4 \\
\hline stratégie & 1 & 14 \\
\hline vision, visionnaire & 1 & 5 \\
\hline gestion, gérer (manage) & 1 & 0 \\
\hline expérience & 2 & 1 \\
\hline légitime, légitimité & 6 & 0 \\
\hline crédible, crédibilité & 0 & 11 \\
\hline
\end{tabular}

First, we have to emphasize that it is usual not to have many hits for the qualities themselves, since we commonly refer to them indexically; i.e., we would never easily or straightforwardly find the phrase he is strategic, but more often: he maneuvered brilliantly. For this study we took into account only the lexical units listed above in the table.

Secondly we can observe a polarisation between the two candidates regarding competence.

Marine Le Pen is clearly referred to as a leader (and mainly in the masculine form): le discours du leader d'extrême droite 'the discourse of the extreme right leader', la présence du leader d'extrême droite dans le trio de tête, 'the presence of the extreme-right leader in the leading trio'; la leader d'extrême droite. She is also seen as a strategic politician, and successful for that matter, while the context of the occurrences is generally positive:

conforte la stratégie offensive de sa présidente Marine Le Pen 'confirms the offensive strategy of its president Marine Le Pen'. (La Croix, 22.03.2011)

méthodiquement, Marine Le Pen impose ses choix, ses hommes, sa stratégie et son projet 'Methodically, Marine Le Pen imposes her choices, her men, her strategy and her project'. (La Croix, 29.04.2011)
Si les contours de ce « rassemblement» sont encore flous, la stratégie, elle, est claire "if the contours of this "gathering" are still to be defined, the strategy is clear'. (Le Monde, 29.03.2011)

This strategic competence makes her even more dangerous as an opponent (Shields 2013). However if being strategic is usually a quality for politicians, in Marine Le Pen's case this is not so clear. Indeed insisting in depicting her as a potential threat may well be a tactic aimed to instill fear in the center or center-right voters: do not take a chance to vote for Le Pen in the first round because the FN may well be the winner against the two favorites, Hollande and Sarkozy. In 2002 her father J.-M. Le Pen, known for his racist views and Holocaust denial statements, wan surprisingly the first round against the socialist L. Jospin; he then found himself in the second round against J. Chirac for the presidency. The latter got $80 \%$ of the vote, so frightened were the French voters to put into power a well-known extreme-right activist.

As for her vision it is noted more frequently than is $\mathrm{M}$. Aubry's, but the context is mitigated: she writes a " livre boussole " pour détailler sa "vision " et son " projet " (a 'guide book' to outline her 'vision' and her 'project'). The credibility of the Front National leader is embedded in an extreme and clearly negative context, since in most occurrences she is presented as striving to be credible: La candidate d'extrême droite, en quête de crédibilité 'the far-right candidate in search of credibility'.

The opposite is found for M. Aubry, whose competence is focused on her legitimacy:

Ils jugent qu'elle a la légitimité pour rassembler tous les socialistes (They consider her to have the legitimacy required to unite all the socialists, and especially the left). (Le Monde, 30.03.2011)

Elle dispose de la légitimité institutionnelle (she has institutional legitimacy). (Le Monde, 20.05.2011)

Bernard Soulage relève la "légitimité institutionnelle de la première secrétaire » (Bernard Soulage notes the "institutional legitimacy of the first secretary"). (Le Monde, 24.05. 2011)

Martine Aubry a joué pleinement auprès des socialistes de sa légitimité institutionnelle. (Martine Aubry has used her institutional legitimacy to good effect with the socialists). (Le Monde, 29.06.2011) 
Moreover the terms representing leadership (a stateswoman) are extremely positive:

C'est la marque d'une femme d'Etat (this is the mark of a stateswoman). (Le Monde, 31.05.2011)

C'est une femme d'Etat proche des gens. (She is a stateswoman close to the people). (Le Monde, 24.05.2011)

This was not true for Marine le Pen, for whom the mentions of leader merely noted her function as a leader of the party but not as a future stateswoman.

To sum up this section, on the one hand, Marine Le Pen is acknowledged as a strategist and a woman with a vision, but she is not seen as credible and no other party wants to be part of her vision. On the other hand, Martine Aubry is legitimate and seen as a real stateswoman, but she has neither a real vision, nor the strategic ability that would make her a truly legitimate leader.

Ambiguous competency thus contributes to the hybridity characterizing their personas in these journalistic discourses. They are presented as unintelligible (Butler 1995 , inter alia) to voters. In Butler's theory 'cultural intelligibility' is what gives access to personhood, it is a means by which a person becomes a subject. Therefore, making a political persona unintelligible is a way to keep him/her outside the domain and field of politics. Indeed 'to find that you are unintelligible $(\ldots)$ is to find that your language is hollow, that no recognition is forthcoming because the norms by which recognition takes place are not in your favor (Butler 2004, p. 30, our italics). Since the norms favor male politicians, as has been demonstrated many times, Martine Aubry and Marine Le Pen may still have a long way to go.

\section{Conclusion: periperformativity and journalistic discourse}

West and Zimmerman (1987), following Goffman's conclusions (1959), deconstructed femininity and masculinity into moments of attribution and iteration. However, if a gendered identity is a continual social process of 'doing' masculinity and femininity, gender does not precede but, rather, follows from practice, instantiated in a person's everyday behavior and micro-actions (Butler 1995). As we saw in this study, each mention of a name in a discourse is an opportunity to construct that entity as feminine or masculine. Moreover, Sedgwick has suggested that we must take into account what she calls periperformativity (2003, pp. 67-91), i.e., society's contribution to the success or failure of a speech act, the success of failure of being constructed, interpreted as feminine / masculine at the right time, in the right place. As we know, repetitive performativities are not interpreted in the same way according to the place and the time they are exhibited, according to who exhibits them and according to who interprets them. The discursive strategies (which are the focus of this paper) may be a good example of this periperformativity as carried out by journalists and by political advisers. Indeed, we have witnessed the construction of a typical double bind: societies with their norms and expectations create an impasse in which women are dammed if they do (a masculine style is not natural) and they are dammed if they don't (a feminine style is inappropriate in politics). Indeed, even if women politicians are able to work differently and better because of a different experience, even if they try to be different and against hegemonic conventions, they will be interpreted by those same conventions and ideologies, notwithstanding the 'unplanned effects of the performance act and the contingencies to be taken into consideration' (Lloyd, 1999). Newspaper articles and journalistic comments are interpretative acts and doing so are sites of exerting power; the emergence of forums and blogs as other sites of (re)interpretation may hopefully subvert the 'mainstream' meaning construction acts: this may be the reason why the Front national like many other extreme right parties is extremely well represented in political forums and in the computer mediated communication in general. 


\section{References}

- Achin, C. \& Dorlin, E. (2008). Nicolas Sarkozy ou la masculinité mascarade du président. Raisons politiques, 31, 19-45

- Achin, C \& Levêque, S. (2012). http://blogs.mediapart.fr/edition/sociologi e-politique-des-

elections/article/100312/femmes-ethommes-en-politique-compren

- Achin, C., Bargel, L., Dulong, D. et alli (2007). Sexes genre et politique. Paris : Economica.

- Allan, C. \& Mas, C. (2007). Femmes et politique. Paris : Ellipses.

- Baider, F. (2009). Ségolène Royal dans la presse française: deuxième sexe, ou second choix ? Modern and Contemporary France 18 (4) 1-15.

- Baider, F. (under revisions). Evaluation de la présidentiabilité. Mots. Les langages du politique.

- Baider, F. \& Jacquey, E. (2010). Substantive Dis-Embodiement, Syntactic Embedment. Feminism, Femininity and Gendered Discourse (eds. J. Holmes \& M. Marra). Cambridge Scholar Press. 145-167.

- Baider, F. \& Jacquey, E. (2014). Data mining for Tracking Gender Bias: a Curse or a Blessing? The 2012 presidential duos. Ecological and Data-Driven Perspectives in French Language Studies (eds H. Tyne et al.). Newcastle upon Tyne: Cambridge Scholar Press. 222245.

- Bednarek, M. (2008). Semantic preference and semantic prosody re-examined. Corpus Linguistics and Linguistic Theory 4 (2) 119 139.

- Bertini, M.-J. (2002). Femmes, le Pouvoir impossible. Paris : Pauvert.

- Blumenthal, P. (2002). Profil combinatoire des noms. Synonymie distinctive et analyse contrastive. Zeitschrift für Französische Sprache und Literatur 112, 115-138.

- Boudillon, J. (2005). Une femme d'extrême droite dans les médias. Le cas de Marine Le
Pen. Mots. Les langages du politique [online], 78 URL : http://mots.revues.org/392

- Butler, J. (1995). Gender trouble. Routledge.

- Coulomb-Gully, M. (2009). Présidentiel 2007. Média genre et politique. Mots, 90(1), 5-11.

- Coulomb-Gully, M. (2012). Présidente : le grand défi. Femmes, politique et médias. Paris : Payot.

- Drouin, P. (2003). Term extraction using non-technical corpora as a point of leverage. Terminology, 9 (1), 99-117.

- Fassin, E. (2008). Des identités politiques. Jeux et enjeux du genre et de la race dans les primaires démocrates aux Etats-Unis en 2008. Raisons politiques, 31,65-79.

- Freedman, J. (1997). Femmes politiques : mythes et symbols. L'Harmattan: Paris.

- Goffman, E. (1959). The Presentation of Self in Everyday Life. University of Edinburgh Social Sciences Research Centre: Anchor editions.

- Grzesitchak, M., Jacquey, E. \& Valette, M. (2007). Systèmes complexes et analyse textuelle : Traits sémantiques et recherche d'isotopies, ARCo'07 - Cognition, Complexité

- http://mathieu.valette.free.fr/Articles/Grz esitchak_Jacquey_Valette_2007.pdf

- Holmes, M. (2004). Feeling beyond rules: Politicizing the Sociology of Emotion and Anger in Feminist Politics. European Journal of Social Theory, 7, 209-227.

- Le Bart, C. (2009). Les présidentiables de 2007 entre proximité et surplomb. Nicolas Sarkozy et Ségolène Royal vus pas Libération. Mots. Les langages du politique, 89, 31-45.

- Lesage, R., Price, W., Bissonnette, C. \& Drouin, P. (1993). Enquête sur l'état d'utilisation des outils automatisés d'aide à la rédaction dans les organisations. META, 38(2), 367-389. 
- Lloyd, M. (1999) Performativity, parody, politics. Theory, Culture and Society, 16(2), 195-213.

- Middleton, D. (1989). Emotional Style: The Cultural Ordering of Emotions. Ethos, 17(2), 187-201.

- Olivesi, A. (2012). Implicitement sexiste ? Toulouse : Presses universitaires du Mirail.

- Reutenauer, C., Valette, M. \& Jacquey, E. (2010). De l'annotation sémique globale à l'interprétation locale : environnement et image sémiques d' 'économie réelle' dans un corpus sur la crise financière. Cognitica Actes du colloque de l'Association pour la Recherche Cognitive Arco'09 (9-11 November 2009, Rouen), 29-39.

- Sedgwick, E. K. (2003) Touching Feeling: Affect, Pedagogy, Performativity. Durham and London: Duke University Press.

- Shields, J. (2007). The extreme right in France : from Pétain to Le Pen. London: Routledge.

- Shields, J. (2013). A Change of Style or of Substance? Parliamentary Affairs, 66(1),179196.
- Sinclair, J. (2004). The search for units of meaning. Trust the Text. Language, Corpus and Discourse. London/New York: Routledge, 24-48.

- Sineau, M. (2001). Profession femme politique : sexe et pouvoir sous la Cinquième République. Paris : Presses de sciences Po.

- Sineau, M. (2007). Effets de genre, effets de génération ? Le vote hommes/femmes à l'élection présidentielle 2007. Revue française de science politique, 3(57), 353-369.

- Tutin, A., Novakova, I., Grossman, F., Cavalla, C. (2006). Esquisse de typologie des noms d'affect à partir de leurs propriétés combinatoires. Langue française, 150, 32-49.

- Van Dijk, T. A. (2006). Discourse and manipulation. Discourse \& Society, 17(2), 359383.

- West, C. \& Zimmerman, D. H. (1987). Doing Gender. Gender and Society, 1(2), 125-151.

\section{Forma de Citación}

BAIDER, Fabienne: Hybrid strategic identities as gendered resources in French politics (Martine Aubry and Marine Le Pen). Revista Communication Papers, $N^{\circ}$, páginas 91 a 102. Departamento de Filología y Comunicación de la Universidad de Girona. Recuperado el _ de de 2

de: http://www.communicationpapers.es 